\title{
Vitamin $D$ receptor gene polymorphisms in association with diabetic nephropathy: a systematic review and meta-analysis
}

\author{
Lina Yang ${ }^{1,2}$, Lan $\mathrm{Wu}^{1}$, Yi Fan ${ }^{2}$ and Jianfei $\mathrm{Ma}^{2^{*}}$ (I)
}

\begin{abstract}
Background: A large amount of researches have demonstrated that vitamin D receptor (VDR) gene polymorphisms are associated with diabetic nephropathy (DN) risk in diabetes mellitus (DM) patients. Nevertheless, the results are inconclusive and inconsistent.

Methods: We screened PubMed, Embase, Chinese National Knowledge Infrastructure and Chinese Wanfang databases for those relevant studies updated in May 2016.

Results: 7 studies involving 2564 subjects were recruited. We evaluated the genotypic and allelic differences between DN patients and DM controls. Overall analysis showed that no significant association was found among the Apal, Bsml, Fokl,Taql gene polymorphisms and DN susceptibility in diabetic patients (all $P$ values $>0.05$ ). In the stratified analysis, $T$ genotype was related to DN susceptibility in Asians ( $T$ vs $T t+t \mathrm{t}: \mathrm{OR}=2.21,95 \% \mathrm{Cl}: 1.05-4.67, p=0.04$ ). The sensitivity analysis showed that the results in overall populations, Caucasians and Asians were dependable.

Conclusions: No significant association was found among the Apal, Bsml, Fokl, Taql polymorphisms and DN risk in overall populations, the Taql variants might related to DN susceptibility in Asians. Further researches are required to testify our meta-analysis.
\end{abstract}

Keywords: Vitamin D receptor, Gene polymorphisms, Diabetic nephropathy, Meta-analysis

\section{Background}

The vascular complications of diabetes mellitus (DM) can lead to high disability rates and mortality rates. Poorly controlled blood glucose leads to the occurrence and development of complications in patients with DM [1]. As one of the most serious diabetic microvascular diseases, diabetic nephropathy (DN) is the main reason of end-stage renal failure(ESRD) [2,3]. Generally, DN is a multifactorial disease attribute to the interaction of environmental and genetic factors $[4,5]$. Several factors always contributing to DN risk include abnormal renal hemodynamic responses, fatty acid metabolism caused by hyperglycemia, hypertension, and abnormal metabolism of vasoactive substances [6]. Recently, genetic predispositions have been found to play a key role in the

\footnotetext{
* Correspondence: majianfei56@sohu.com

${ }^{2}$ Department of Nephrology, the First Affiliated Hospital of China Medical University, 155th Nanjing North Street, Shenyang, Liaoning 110001, People's Republic of China

Full list of author information is available at the end of the article
}

development and progression of DN $[7,8]$. Thus, searching for genetic markers for DN can identify patients who may benefit from prevention.

Previous studies showed that vitamin D endocrine system played an important role in the development of DM [9-11]. High levels of vitamin D can enhance pancreatic b-cell secretion functions and improve insulin resistance $[12,13]$. There are accumulating evidences to suggest that vitamin $\mathrm{D}$ participated in a number of diseases such as DM and DN [14-16]. An increasing number of researches showed that there was a relationship between vitamin D receptor (VDR) gene polymorphisms and DN $[17,18]$. Vitamin D exerts its functions by binding to the nuclear or cytosolic VDR, which serves as a transcription activator and is a member of the steroid / thyroid hormone receptor family [17]. At present, the most common studied single nucleotide polymorphisms (SNPs) of VDR are FokI (rs10735810), BsmI (rs1544410), ApaI (rs7975232) and TaqI (rs731236) [19, 20]. 
To provide an accurate estimation, we operated a systematic review to investigate the relation of $\mathrm{DN}$ and the four VDR gene polymorphisms(ApaI, BsmI, FokI and TaqI).

\section{Methods}

\section{Search strategy}

The related articles were searched from PubMed, Embase, Chinese National Knowledge Infrastructure and Chinese Wanfang databases. The The retrieval strategy were as follows: "VDR, vitamin D receptor, diabetic nephropathy (DN), ApaI, BsmI, FokI, TaqI, polymorphism, genotype". In addition, we retrieved references of selected articles. Here are the inclusion criteria: 1) case-control study; 2)DN as ending; 3) carried out in human population; 4) Clearly define genetic variants of case and control can offer sufficient calculational data. Here are the exclusion criteria: (1) case reports or review articles; (2) articles that did not offer the detailed genotype information; (3) studies on the correlation between DN and other genes; (4) studies investigate the role of VDR genotype in other diseases. The largest or most recent study was selected when continuous or multiple publications that occur under the same search condition [21].

\section{Data extraction}

For each study the following information was evaluated independently by two investigators according to the standard protocol:(1) name of first author; (2) year of publication; (3) original country; (4) ethnicity of the subjects; (5) genotype distribution or allele frequencies; and (6) number of cases and controls (Table 1). Genotypes for the VDR gene polymorphisms(ApaI, BsmI, FokI or TaqI) were designated with $\mathrm{A}, \mathrm{B}, \mathrm{F}$ and $\mathrm{T}$ for the absence of restriction sites and with $a, b, f$ and $t$ for their presence. In most studies, the ApaI, BsmI, FokI or TaqI genotype and allele frequency of the VDR gene were measured by PCR-restriction fragment length polymorphism (PCR-RFLP). In one study [22], pyrosequencing reactions were performed to determine the BsmI, FokI or TaqI genotype, Taqman 5'-nuclease assays were performed used to determine the ApaI genotype, the labels of FokI $(\mathrm{C} / \mathrm{T})$ are correspond to FokI (F/ f),BsmI (A/G) are correspond to BsmI (B/b),ApaI ( $\mathrm{T} /$ G) are correspond to ApaI (A/a),TaqI(T/C) are correspond to $\operatorname{TaqI}(\mathrm{T} / \mathrm{t})$.

\section{Statistical analysis}

The odds ratio (OR) with 95\% confidence interval (CI) were used to evaluate the association among the four VDR gene polymorphisms and DN risk. Statistical

Table 1 Characteristics of the studies evaluating the effects of VDR Bsml,Fokl, Taql and Apal gene polymorphisms on DN risk

\begin{tabular}{|c|c|c|c|c|c|c|c|c|c|c|c|c|c|c|}
\hline \multirow{2}{*}{$\begin{array}{l}\text { Gene } \\
\text { sites } \\
\text { Bsml }\end{array}$} & \multirow{2}{*}{$\begin{array}{l}\text { Author } \\
\text { year }\end{array}$} & \multirow[t]{2}{*}{ Ethnicity } & \multirow[t]{2}{*}{ Country } & \multirow{2}{*}{$\begin{array}{l}\text { Type } \\
\text { of DM }\end{array}$} & \multirow{2}{*}{$\begin{array}{l}\text { Sex } \\
\text { male/female }\end{array}$} & \multicolumn{4}{|l|}{ Case } & \multicolumn{4}{|c|}{ Control } & \multirow[t]{2}{*}{$\operatorname{HWE}(p)$} \\
\hline & & & & & & $\mathrm{BB}$ & $\mathrm{Bb}$ & $\mathrm{bb}$ & Total & $\mathrm{BB}$ & $\mathrm{Bb}$ & $\mathrm{bb}$ & Total & \\
\hline & Bućan 2009 & Caucasian & Croatia & DM1 & $-1-$ & 1 & 8 & 5 & 14 & 6 & 18 & 9 & 33 & 0.566 \\
\hline & Martin 2009 & Caucasian & Ireland & DM1 & Case 359/296 & 106 & 321 & 228 & 655 & 111 & 325 & 238 & 674 & 0.998 \\
\hline & & & & & Control 286/388 & & & & & & & & & \\
\hline & Zhang 2012 & Asian & China & $\mathrm{DM} 2$ & Case $99 / 83$ Control 68/54 & 3 & 57 & 122 & 182 & 0 & 26 & 96 & 122 & 0.188 \\
\hline \multirow[t]{5}{*}{ Fokl } & & & & & & $\mathrm{FF}$ & $\mathrm{Ff}$ & $\mathrm{ff}$ & Total & FF & Ff & $\mathrm{ff}$ & Total & \\
\hline & Li 2005 & Asian & China & $\mathrm{DM} 2$ & $30 / 64$ & 9 & 17 & 13 & 39 & 28 & 22 & 5 & 55 & 0.821 \\
\hline & Bućan 2009 & Caucasian & Croatia & DM1 & $-1-$ & 4 & 6 & 4 & 14 & 9 & 18 & 6 & 33 & 0.566 \\
\hline & Martin 2009 & Caucasian & Ireland & DM1 & Case $359 / 296$ Control 286/388 & 248 & 323 & 84 & 655 & 262 & 311 & 101 & 674 & 0.580 \\
\hline & Vedralová 2012 & Caucasian & Czech & $\mathrm{DM} 1 / 2$ & Case 75/57 Control 94/76 & 63 & 58 & 11 & 132 & 57 & 85 & 28 & 170 & 0.696 \\
\hline \multirow[t]{5}{*}{ Taql } & & & & & & $\Pi$ & $\mathrm{Tt}$ & $\mathrm{tt}$ & Total & $\pi$ & $\mathrm{Tt}$ & $\mathrm{tt}$ & Total & \\
\hline & Bućan 2009 & Caucasian & Croatia & DM1 & $-1-$ & 5 & 6 & 3 & 14 & 13 & 14 & 6 & 33 & 0.522 \\
\hline & Martin 2009 & Caucasian & Ireland & DM1 & Case 359/296 Control 286/388 & 103 & 327 & 225 & 655 & 98 & 327 & 249 & 674 & 0.575 \\
\hline & Nosratabadi 2010 & Asian & Iran & $\mathrm{DM} 2$ & Case 38/62 Control 41/59 & 9 & 55 & 36 & 100 & 4 & 63 & 33 & 100 & 0 \\
\hline & Han 2015 & Asian & China & $\mathrm{DM} 2$ & $150 / 138$ & 102 & 6 & 0 & 108 & 160 & 16 & 4 & 180 & 0 \\
\hline \multirow[t]{5}{*}{ Apal } & & & & & & AA & $\mathrm{Aa}$ & aa & Total & AA & $\mathrm{Aa}$ & aа & Total & \\
\hline & Martin 2009 & Caucasian & Ireland & DM1 & Case 359/296 Control 286/388 & 185 & 323 & 147 & 655 & 200 & 322 & 152 & 674 & 0.303 \\
\hline & Nosratabadi 2010 & Asian & Iran & DM2 & Case 38/62 Control 41/59 & 9 & 64 & 27 & 100 & 9 & 63 & 28 & 100 & 0.002 \\
\hline & Zhang 2012 & Asian & China & $\mathrm{DM} 2$ & Case 99/83 Control 68/54 & 19 & 89 & 74 & 182 & 11 & 65 & 46 & 122 & 0.075 \\
\hline & Han 2015 & Asian & China & DM2 & $150 / 138$ & 2 & 50 & 56 & 108 & 18 & 80 & 82 & 180 & 0.814 \\
\hline
\end{tabular}


analysis were divided into Caucasian and Asian populations in subgroup analysis. The Chi-square based Q-statistic test was used to assess the heterogeneity between the studies. $P<0.10$ indicated there is a significant heterogeneity among the studies. If the $P$ value was no more than 0.1 , pooled OR was estimated using a random-effect model using the DerSimonian and Laird method $(\mathrm{D}+\mathrm{L})$, otherwise a fixed-effect model using the Mantel-Haenszel (MH) method was carried out. The asymmetry funnel plots were used to estimate the publication bias. The exact test was carried out to assess whether the genotype distribution in control population were accord with Hardy-Weinberg equilibrium (HWE) expectations. A sensitivity analysis of the overall population was used by omitting one study in each turn. Cochrane Review Manager Version 5.1 (Cochrane Library, Oxford, UK) was used to performed the statistical analyses. All the $P$ values were double tailed test and the significance was set at $P<0.05$.

\section{Results}

Characteristics of the studies

The search yielded 67 articles, 7 studies [18, 22-27] contain $1230 \mathrm{DN}$ patients and 1334 diabetic controls were finally recruited into our meta-analysis according to the inclusion and exclusion criteria, all studies reporting the association among ApaI, BsmI, FokI, TaqI of VDR gene polymorphisms and DN susceptibility (Fig. 1). The main characteristics of these selected studies were summarized in Table 1, including the first author's name, year of publication, original country and genotype distribution.

\section{Quantitative data synthesis}

It has been shown in Table 2 that the risk for DN conferred by VDR gene polymorphisms did not show significant difference in the overall 7 studies (all $P$ values $>0.05$ ) (Figs. 2, 3, 4 and 5).In the stratified analysis, there was a relationship between TT genotype and DN risk in Asians in only two studies of 488 patients(TT vs $\mathrm{Tt}+\mathrm{tt}$ : $\mathrm{OR}=2.21,95 \%$ CI: $1.05-4.67, p=0.04)$, however, $p$ value equals to 0.04 seems not enough to support relationship

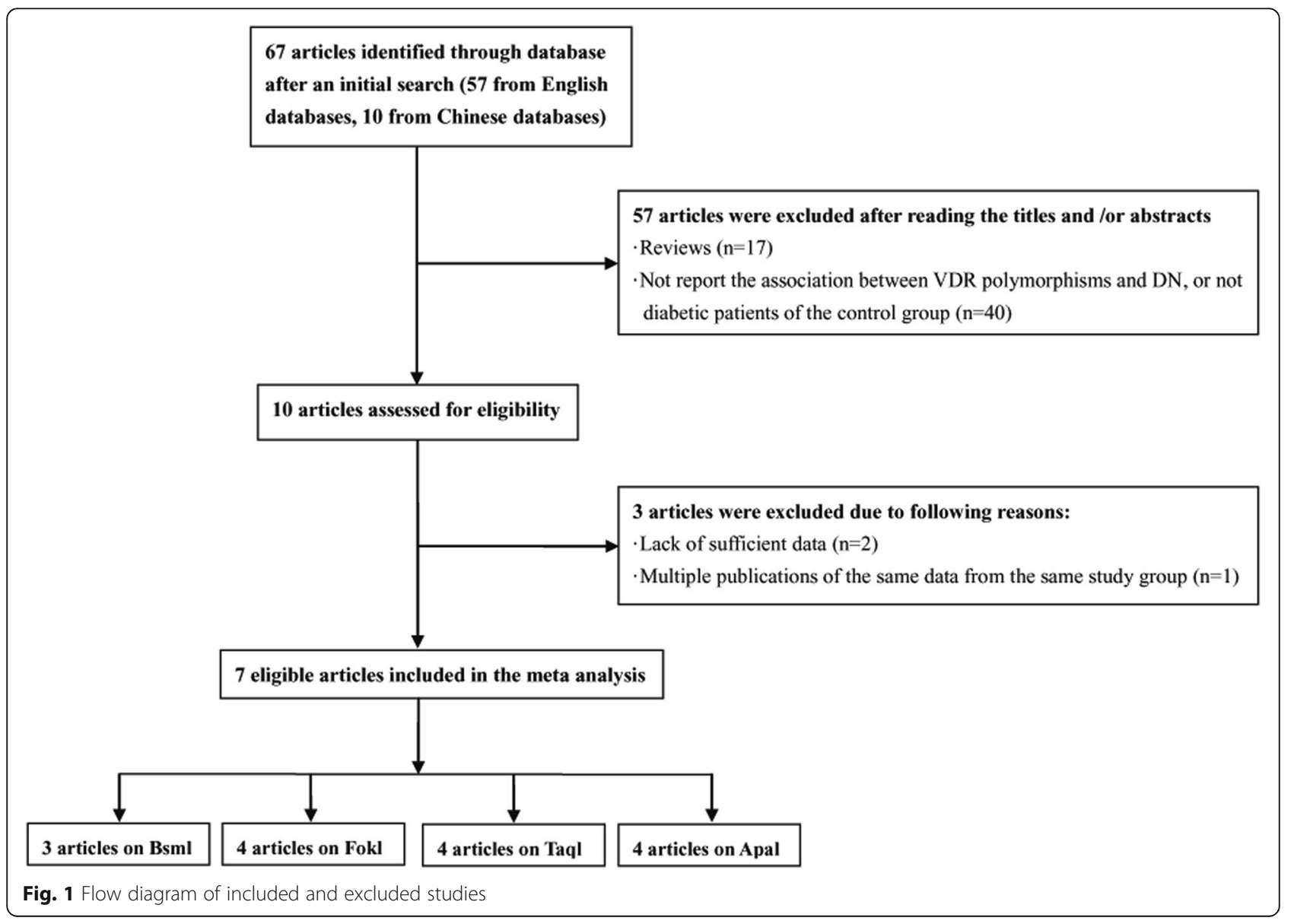


Table 2 Meta analysis of the association of VDR Bsml,Fokl, Taql and Apal gene polymorphisms with DN risk

\begin{tabular}{|c|c|c|c|c|c|c|}
\hline $\begin{array}{l}\text { Genetic } \\
\text { contrasts }\end{array}$ & $\begin{array}{l}\text { Group and } \\
\text { subgroups }\end{array}$ & $\begin{array}{l}\text { Studies } \\
\text { number }\end{array}$ & $\begin{array}{l}Q \text { test } p \\
\text { value }\end{array}$ & $\begin{array}{l}\text { Model } \\
\text { selected }\end{array}$ & $\mathrm{OR}(95 \% \mathrm{Cl})$ & $\mathrm{p}$ \\
\hline \multicolumn{7}{|l|}{ Bsml } \\
\hline \multirow[t]{3}{*}{$B$ vs $b$} & Overall & 3 & 0.06 & Random & $1.13[0.72,1.75]$ & 0.60 \\
\hline & Caucasian & 2 & 0.39 & Fixed & $0.99[0.85,1.16]$ & 0.93 \\
\hline & Asian & 1 & - & Fixed & $1.75[1.08,2.86]$ & 0.02 \\
\hline \multirow[t]{3}{*}{$B B$ vs $B b+b b$} & Overall & 3 & 0.38 & Fixed & $0.98[0.74,1.30]$ & 0.89 \\
\hline & Caucasian & 2 & 0.36 & Fixed & $0.96[0.72,1.28]$ & 0.77 \\
\hline & Asian & 1 & - & Fixed & $4.78[0.24,93.31]$ & 0.30 \\
\hline \multirow[t]{3}{*}{$b b$ vs $B B+B b$} & Overall & 3 & 0.11 & Random & $0.84[0.53,1.33]$ & 0.45 \\
\hline & Caucasian & 2 & 0.55 & Fixed & $0.99[0.79,1.24]$ & 0.93 \\
\hline & Asian & 1 & - & Fixed & $0.55[0.32,0.94]$ & 0.03 \\
\hline \multicolumn{7}{|l|}{ Fokl } \\
\hline \multirow[t]{3}{*}{$F v s f$} & Overall & 4 & 0.0001 & Random & $0.88[0.52,1.48]$ & 0.62 \\
\hline & Caucasian & 3 & 0.04 & Random & $1.19[0.81,1.73]$ & 0.38 \\
\hline & Asian & 1 & - & Fixed & $0.33[0.18,0.61]$ & 0.0004 \\
\hline \multirow[t]{3}{*}{$F F$ vs Ff $+f f$} & Overall & 4 & 0.004 & Random & $0.92[0.50,1.71]$ & 0.80 \\
\hline & Caucasian & 3 & 0.05 & Random & $1.24[0.74,2.05]$ & 0.41 \\
\hline & Asian & 1 & - & Fixed & $0.29[0.12,0.72]$ & 0.008 \\
\hline \multirow[t]{3}{*}{$f f v s F F+F f$} & Overall & 4 & 0.005 & Random & $1.18[0.52,2.72]$ & 0.69 \\
\hline & Caucasian & 3 & 0.18 & Fixed & $0.78[0.59,1.03]$ & 0.08 \\
\hline & Asian & 1 & - & Fixed & $5.00[1.61,15.56]$ & 0.005 \\
\hline \multicolumn{7}{|l|}{ Taql } \\
\hline \multirow[t]{3}{*}{ T vs $t$} & Overall & 4 & 0.20 & Fixed & $0.96[0.84,1.11]$ & 0.62 \\
\hline & Caucasian & 2 & 0.89 & Fixed & $0.92[0.79,1.08]$ & 0.30 \\
\hline & Asian & 2 & 0.09 & Random & $1.46[0.63,3.38]$ & 0.37 \\
\hline \multirow[t]{3}{*}{$\pi \mathrm{vs} T \mathrm{t}+\mathrm{tt}$} & Overall & 4 & 0.15 & Fixed & $0.97[0.79,1.20]$ & 0.77 \\
\hline & Caucasian & 2 & 0.95 & Fixed & $0.89[0.71,1.11]$ & 0.31 \\
\hline & Asian & 2 & 0.89 & Fixed & $2.21[1.05,4.67]$ & 0.04 \\
\hline \multirow[t]{3}{*}{$\mathrm{tt} v \mathrm{v} T+\mathrm{Tt}$} & Overall & 4 & 0.68 & Fixed & $1.08[0.83,1.40]$ & 0.56 \\
\hline & Caucasian & 2 & 0.89 & Fixed & $1.10[0.82,1.48]$ & 0.52 \\
\hline & Asian & 2 & 0.22 & Fixed & $1.01[0.58,1.77]$ & 0.97 \\
\hline \multicolumn{7}{|l|}{ Apal } \\
\hline \multirow[t]{3}{*}{ A vs a } & Overall & 4 & 0.44 & Fixed & $0.94[0.83,1.07]$ & 0.35 \\
\hline & Caucasian & 1 & - & Fixed & $0.97[0.84,1.13]$ & 0.73 \\
\hline & Asian & 3 & 0.33 & Fixed & $0.89[0.72,1.10]$ & 0.26 \\
\hline \multirow[t]{3}{*}{$\mathrm{AA}$ vs $\mathrm{Aa}+\mathrm{aa}$} & Overall & 4 & 0.14 & Fixed & $0.89[0.72,1.11]$ & 0.31 \\
\hline & Caucasian & 1 & - & Fixed & $0.93[0.74,1.18]$ & 0.57 \\
\hline & Asian & 3 & 0.06 & Fixed & $0.73[0.43,1.23]$ & 0.24 \\
\hline \multirow[t]{3}{*}{ aa vs $A A+A a$} & Overall & 4 & 0.79 & Fixed & $1.06[0.87,1.28]$ & 0.58 \\
\hline & Caucasian & 1 & - & Fixed & $0.99[0.77,1.29]$ & 0.96 \\
\hline & Asian & 3 & 0.75 & Fixed & $1.14[0.85,1.53]$ & 0.37 \\
\hline
\end{tabular}




\begin{tabular}{|c|c|c|c|c|c|c|c|}
\hline \multirow[b]{2}{*}{ Study or Subgroup } & \multicolumn{2}{|c|}{ Experimental } & \multicolumn{2}{|c|}{ Control } & \multirow{2}{*}{\multicolumn{2}{|c|}{$\begin{array}{l}\text { Odds Ratio } \\
\text { M-H. Random, } 95 \% \text { cl Year }\end{array}$}} & \multirow{2}{*}{$\begin{array}{l}\text { Odds Ratio } \\
\mathrm{M}-\mathrm{H} . \text { Random, } 95 \% \mathrm{Cl}\end{array}$} \\
\hline & Events & Total & Events & Total & & & \\
\hline Kajo Bućan 2009 & 10 & 28 & 30 & 66 & $16.4 \%$ & $0.67[0.27,1.66] 2009$ & $\longrightarrow$ \\
\hline Rosalind J.L.Martin 2010 & 533 & 1310 & 547 & 1348 & $51.0 \%$ & $1.00[0.86,1.17] 2010$ & \\
\hline Zhang 2012 & 63 & 364 & 26 & 244 & $32.6 \%$ & $1.75[1.08,2.86] 2012$ & $\Rightarrow$ \\
\hline Total $(95 \% \mathrm{Cl})$ & & 1702 & & 1658 & $100.0 \%$ & $1.13[0.72,1.75]$ & \\
\hline \multirow{2}{*}{\multicolumn{7}{|c|}{ Heterogeneity: $\mathrm{Tau}^{2}=0.09 ; \mathrm{Ch}^{2}=5.50, \mathrm{df}=2(P=0.06) ; \mathrm{I}^{2}=64 \%$}} & \\
\hline & & & & & & & $\begin{array}{|lllll|}0.01 & 1 & & 1 & \\
& 1 & 10 & 100\end{array}$ \\
\hline \multicolumn{7}{|c|}{ Test for overall effect: $Z=0.53(P=0.60)$} & Allele model (B versus b) \\
\hline
\end{tabular}

between genetic variant and diabetic nephropathy. Besides, there was no significant correlation between other three polymorphisms and DN risk in Asians and Caucasians(Table 2). Altogether, the results of the metaanalysis can be described as negative. Particularly worth mentioning is that only one published study in Asian populations was included in the BsmI and FokI groups, the subgroup for Asians might not be reliable in these two groups. Two studies [24, 27] were excluded because the genotype distributions in controls were obviously deviated from the HWE. Sensitivity analysis showed that the results were dependable for overall populations, Caucasians and Asians.

\section{Publication bias}

Begg's funnel plots and Egger's test were carried out to analyse the publication bias. Results showed that there was no evidence of publication bias in the 7 studies (data not shown). However, due to the small number of studies, publication bias cannot be ruled-out in this paper.

\section{Discussion}

$\mathrm{DN}$ is the most common microvascular complication in diabetes patients, and the most common reason of ESRD in the United States [28]. 40\% DM patients suffer from $\mathrm{DN}$, and the occurrence have no association with hyperglycemia, suggesting genetic factors may be involved in the development of DN $[29,30]$.Currently, VDR has also been illustrated to be associated with the occurrence and development of DN [31].

The vitamin $\mathrm{D}$ has important biological functions, such as modulating immunity system, influencing insulin secretion and improving insulin resistance [32, 33], which are involved in the etiology of DN and more likely to be influenced by VDR gene polymorphisms. Given the controversial results from published individual studies with small sample sizes, we carried out a metaanalysis to clarify the association between the VDR gene polymorphisms and susceptibility to DN.

The VDR gene is located on chromosome 12 at q12-q14, it has14eons, 8 protein-coding exons and 6 untranslated region. ApaI and BsmI VDR gene variants locate in intron 8 and TaqI variants locate in exon 9. The FokI variants locate in the codon initiating translation, which has been reported to cause severe protein dificiency [25]. A large amount of common chronic disorder diseases, such as type 1 and type $2 \mathrm{DM}$, have been found to be relevant to specified VDR gene polymorphisms [34]. The effects of VDR gene polymorphisms on gene expression are still not clearly understood. VDR gene variants may have effect on RNA translational efficiency [35]. Distinctions of VDR mRNA express level and stability can affect the activity of renin-angiotensin system and participate in the progress of $\mathrm{DN}[26,27]$.

In this study, we analyzed the VDR gene functional polymorphisms (ApaI, BsmI, FokI and TaqI) as

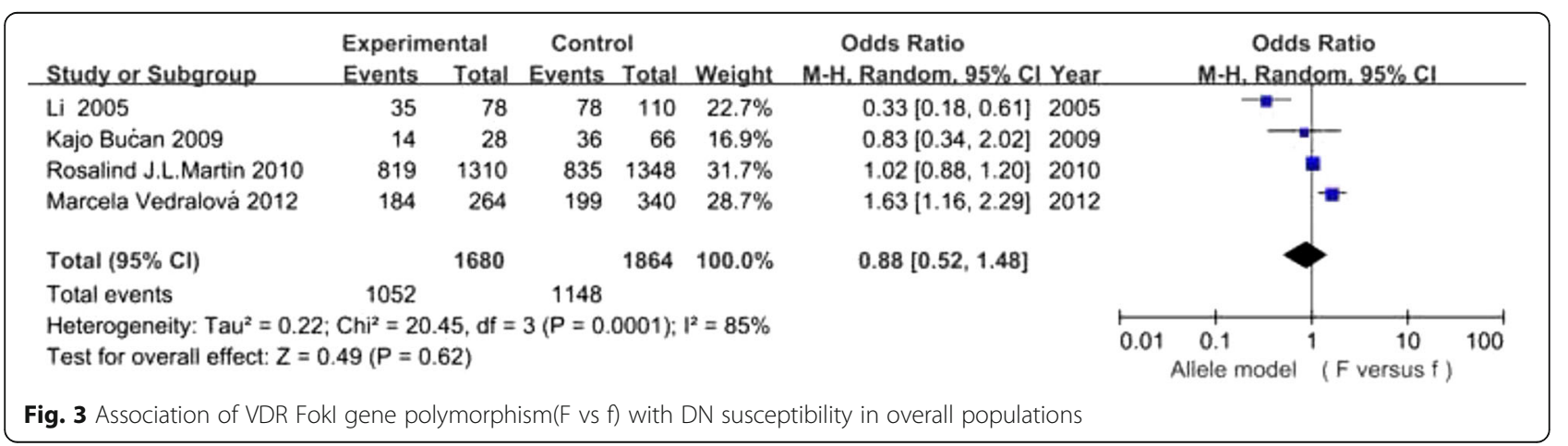




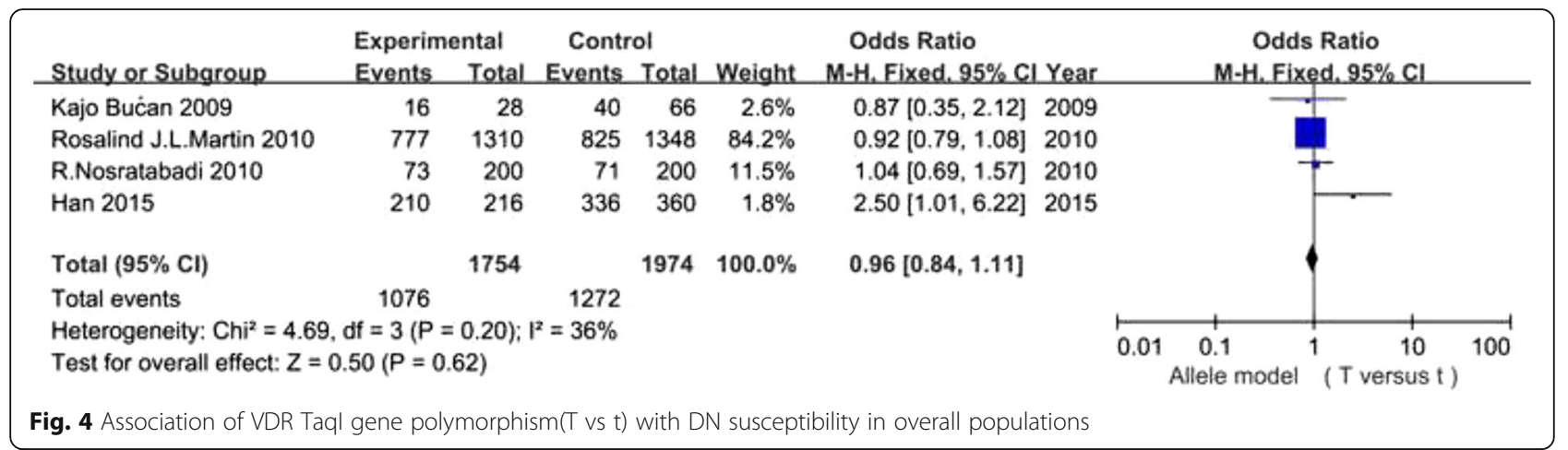

potential genetic markers for DN. Nevertheless, the results of our research showed that none of these polymorphisms was significantly associated with DN risk in diabetic patients in overall population(all $P$ values $>0.05$ ). Since genetic factors can affect the results of meta analysis, subgroup analysis were also preformed by race for the four polymorphisms. Our results indicate that there was a relationship between TT genotype and $\mathrm{DN}$ risk in Asians (TT vs Tt + tt: OR $=2.21,95 \%$ CI: $1.05-4.67, p=0.04$ ), however, $p$ value equals to 0.04 seems not enough to support relationship between genetic variants and DN. Since only one published study in Asian populations was included in the BsmI and FokI groups, the stratified analysis for Asians might not be reliable in these two groups. Besides, there was no significant associations among the other three gene variants and DN in Caucasians and Asians(Table 2). Altogether, the results of the metaanalysis can be described as negative. Liu [34] reported that the FokI gene variants was related to DN susceptibility in Caucasians. We have a different result, and we performed a more comprehensive research on the association among four gene polymorphisms (ApaI, BsmI, FokI and TaqI) of VDR and DN risk. However, further large-scale studies should be carried out to testify our research.

For better understanding of the results, several limitations in our study should be mentioned. First, the number of subjects were relatively small, so we lacked sufficient statistical power to estimate the associations between VDR gene variants and susceptibility to DN. Second, metaanalysis is a retrospective study that may cause selection bias, which may have an impact on the reliability of results. Third, our study failed to acquire raw data from the selected articles, which may lead to further limitation in the assessment of potential effects of VDR gene polymorphisms in the occurrence and progression of $\mathrm{DN}$.

Our research provide evidence that VDR TaqI polymorphism may be relevant to the risk of DN in DM patients among Asians. However, the number of articles included is really small, which is an important limit, and with such a small number of studies, subgroup (Asian/ Caucasian) results we reported have to be considered as exploratory. Martin et al.'s [22] is by far the largest sample size study in our research. Consequently, the overall meta-analysis report results very close to those of Martin et al. Therefore, large-scale studies are still needed to provide a more representative meta-analysis.

\section{Conclusions}

In conclusion, our meta-analysis showed that no significant association was observed among the ApaI, BsmI, FokI and TaqI variants and DN susceptibility in overall populations, the TaqI variants may be associated with DN risk in Asian populations. Future larger scale epidemiological investigation of this topic should be conducted to confirm or refute our findings.

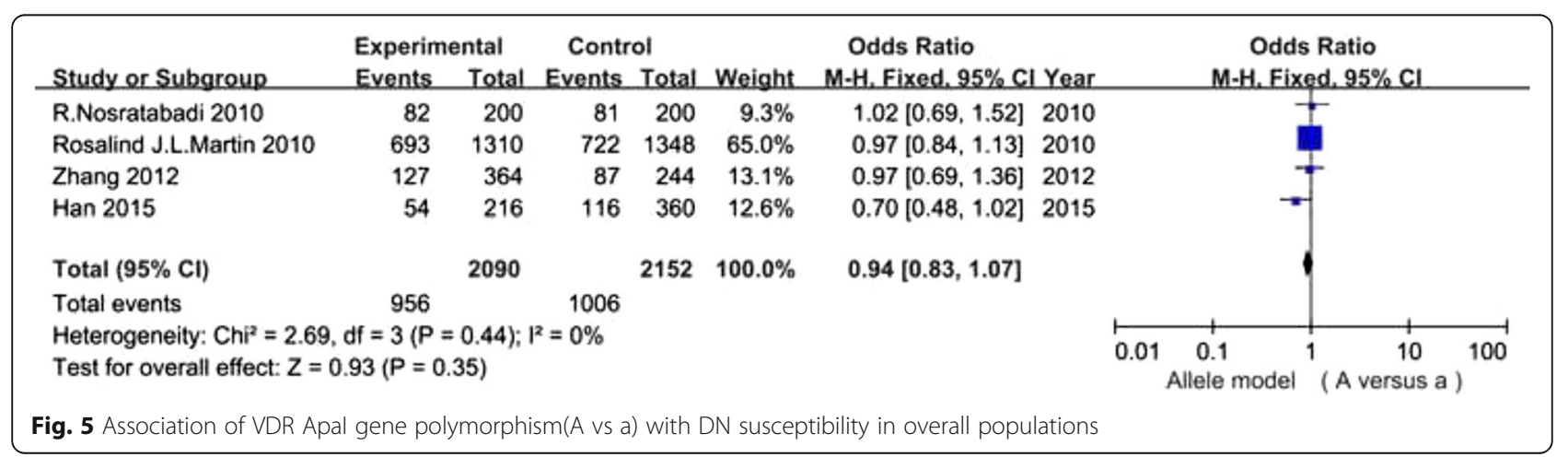




\section{Abbreviations}

Cl: Confidence interval; D + L: DerSimonian and Laird method; DM: Diabetes mellitus; DN: Diabetic nephropathy; ESRD: End-stage renal failure; HWE: Hardy-Weinberg equilibrium; M-H: Mantel-Haenszel.; OR: Odds ratio; SNPS: Single nucleotide polymorphisms; VDR: Vitamin D receptor

\section{Acknowledgements}

We want to thank all members of the Department of Central Laboratory for their collaboration.

\section{Funding}

This research was supported by the National Natural Science Foundation of China(Grant No. 81300636 and Grant No. 81370865)

\section{Availability of data and materials}

Material and data requirements can be sent to the corresponding author.

\section{Authors' contributions}

LY and LW conceived the experiment. YF and JM performed the data search and extraction. LY and YF collected and analyzed the data. YF and JM carried out meta-analysis. LY wrote the paper. LW, YF and JM reviewed the draft. All authors have read and are in agreement with the submitted manuscript.

\section{Ethics approval and consent to participate}

Not applicable.

\section{Consent for publication}

Not applicable.

\section{Competing interests}

The authors declare that no competing interests exist.

\section{Publisher's Note}

Springer Nature remains neutral with regard to jurisdictional claims in published maps and institutional affiliations.

\section{Author details}

'Department of Geriatrics, the First Affiliated Hospital of China Medical University, 155th Nanjing North Street, Shenyang, Liaoning 110001, People's Republic of China. ${ }^{2}$ Department of Nephrology, the First Affiliated Hospital of China Medical University, 155th Nanjing North Street, Shenyang, Liaoning 110001, People's Republic of China.

Received: 10 November 2016 Accepted: 24 August 2017

\section{Published online: 29 August 2017}

\section{References}

1. Phillips CA, Molitch ME. The relationship between glucose control and the development and progression of diabetic nephropathy. Curr Diab Rep. 2002;2(6):523-9.

2. Brown W. Microvascular complications of diabetes mellitus: renal protection accompanies cardiovascular protection. Am J Cardiol. 2008; 102(12A):10L-3L.

3. Duran-Salgado MB, Rubio-Guerra AF. Diabetic nephropathy and inflammation. World J Diabetes. 2014;5(3):393-8.

4. Nelson PJ, Alpers CE. Glomerular disease in 2011: new clues to environmental influences in glomerular disease. Nat Rev Nephrol. 2011; 8(2):65-6.

5. Villeneuve LM, Natarajan R. The role of epigenetics in the pathology of diabetic complications. Am J Physiol Renal Physiol. 2010;299(1):14-25.

6. Kanwar YS, Sun L, Xie P, Liu FY, Chen S. A glimpse of various pathogenetic mechanisms of diabetic nephropathy. Annu Rev Pathol. 2011;6:395-423.

7. Zhang H, Zhu S, Chen J, Tang Y, Hu H, Mohan V, et al. Peroxisome proliferator-activated receptor gamma polymorphism Pro12Ala is associated with nephropathy in type 2 diabetes: evidence from meta-analysis of 18 studies. Diabetes Care. 2012;35(6):1388-93.

8. Su X, Chen X, Liu L, Chang X, Yu X, Sun K. Intracellular adhesion molecule-1 K469E gene polymorphism and risk of diabetic microvascular complications: a meta-analysis. PLoS One. 2013;8(7):e69940.
9. Chertow BS, Sivitz WI, Baranetsky NG, Clark SA, Waite A, Deluca HF. Cellular mechanisms of insulin release: the effects of vitamin $D$ deficiency and repletion on rat insulin secretion. Endocrinology. 1983;113(4):1511-8.

10. Bourlon PM, Billaudel B, Faure-Dussert A. Influence of vitamin D3 deficiency and 1,25 dihydroxyvitamin D3 on de novo insulin biosynthesis in the islets of the rat endocrine pancreas. J Endocrinol. 1999;160(1):87-95.

11. Baynes KC, Boucher BJ, Feskens EJ, Kromhout D. Vitamin D, glucose tolerance and insulinaemia in elderly men. Diabetologia. 1997:40(3):344-7.

12. Pittas AG, Lau J, Hu FB, Dawson-Hughes B. The role of vitamin D and calcium in type 2 diabetes. A systematic review and meta-analysis. J Clin Endocrinol Metab. 2007;92(6):2017-29.

13. Ozfirat Z, Chowdhury TA. Vitamin D deficiency and type 2 diabetes. Postgrad Med J. 2010;86(1011):18-25.

14. Al-Daghri NM, Al-Attas O, Alokail MS, Alkharfy KM, Draz HM, Agliardi C, et al. Vitamin D receptor gene polymorphisms and HLA DRB1*04 cosegregation in Saudi type 2 diabetes patients. J Immunol. 2012;188(3):1325-32.

15. Fernandez-Juarez G, Luno J, Barrio V, de Vinuesa SG, Praga M, Goicoechea $M$, et al. $25(\mathrm{OH})$ vitamin $D$ levels and renal disease progression in patients with type 2 diabetic nephropathy and blockade of the renin-angiotensin system. Clin J Am Soc Nephrol. 2013;8(11):1870-6.

16. Tian XQ, Zhao LM, Ge JP, Zhang Y, Xu YC. Elevated urinary level of vitamin D-binding protein as a novel biomarker for diabetic nephropathy. Exp Ther Med. 2014;7(2):411-6.

17. Li L, Wu B, Liu JY, Yang LB. Vitamin D receptor gene polymorphisms and type 2 diabetes: a meta-analysis. Arch Med Res. 2013;44(3):235-41.

18. Zhang H, Wang J, Yi B, Zhao Y, Liu Y, Zhang K, et al. Bsml polymorphisms in vitamin $D$ receptor gene are associated with diabetic nephropathy in type 2 diabetes in the Han Chinese population. Gene. 2012;495(2):183-8.

19. Zmuda JM, Cauley JA, Ferrell RE. Molecular epidemiology of vitamin D receptor gene variants. Epidemiol Rev. 2000;22(2):203-17.

20. Uitterlinden $A G$, Fang $Y$, Van Meurs JB, Pols HA, Van Leeuwen JP. Genetics and biology of vitamin D receptor polymorphisms. Gene. 2004;338(2):143-56

21. Little J, Bradley L, Bray MS, Clyne M, Dorman J, Ellsworth DL, et al. Reporting, appraising, and integrating data on genotype prevalence and gene-disease associations. Am J Epidemiol. 2002;156(4):300-10.

22. Martin RJ, McKnight AJ, Patterson CC, Sadlier DM, Maxwell AP. Warren 3/UK GoKinD study group. A rare haplotype of the vitamin D receptor gene is protective against diabetic nephropathy. Nephrol Dial Transplant. 2010;25(2):497-503.

23. Bucan K, Ivanisevic M, Zemunik T, Boraska V, Skrabić V, Vatavuk Z, et al. Retinopathy and nephropathy in type 1 diabetic patients-association with polymorphisms of vitamin D-receptor, TNF, Neuro-D and IL-1 receptor 1 genes. Coll Antropol. 2009;33(Suppl 2):99-105.

24. Nosratabadi R, Arababadi MK, Salehabad VA, Shamsizadeh A, Mahmoodi M, Sayadi AR, et al. Polymorphisms within exon 9 but not intron 8 of the vitamin $D$ receptor are associated with the nephropathic complication of type-2 diabetes. Int J Immunogenet. 2010;37(6):493-7.

25. Vedralová M, Kotrbova-Kozak A, Zelezníková V, Zoubková H, Rychlík I, Cerná M. Polymorphisms in the vitamin D receptor gene and parathyroid hormone gene in the development and progression of diabetes mellitus and its chronic complications, diabetic nephropathy and non-diabetic renal disease. Kidney Blood Press Res. 2012:36(1):1-9.

26. Li HM, Miao H, Lu YB, Cheng JL, Geng HF, Jiang XQ. Association between the polymorphism of human vitamin D receptor gene and the susceptibility of diabetic nephropathy in Chinese Han population. Chin J Clin Rehabil. 2005;9(47):1-3.

27. Rui HAN, Xia DONG, Bingchi SU, Wei YANG, Hua LIU, Dianping SONG. Association between Taql , Apal of vitamin D receptor gene polymorphism and type 2 diabetic nephropathy of the Han nationality in Kunming. China Medical Herald. 2015:12(9):69-72.

28. Tuttle KR. Protein kinase C-beta inhibition for diabetic kidney disease. Diabetes Res Clin Pract. 2008:82:70-4.

29. Liu ZH. Diabetic nephropathy genetic background research. Chin Med J. 2002;4(8):561-2.

30. Satko SG, Sedor JR, lyengar SK, Freedman BI. Familial clustering of chronic kidney disease. Semin Dial. 2007:20(3):229-36.

31. Reis AF, Hauache OM, Velho G. Vitamin D endocrine system and the genetic susceptibility to diabetes, obesity and vascular disease. A review of evidence. Diabetes Metab. 2005;31(4 Pt 1):318-25.

32. Lemire J. 1,25-Dihydroxyvitamin D3-a hormone with immunomodulatory properties. Z Rheumatol. 2000;59:24-7. 
33. Garbossa SG, Folli F. Vitamin D, sub-inflammation and insulin resistance. A window on a potential role for the interaction between bone and glucose metabolism. Rev Endocr Metab Disord. 2017;18(2):241-58.

34. Liu Z, Liu L, Chen X, He W, Yu X. Associations study of vitamin D receptor gene polymorphisms with diabetic microvascular complications: a metaanalysis. Gene. 2014;546(1):6-10.

35. Valdivielso JM, Fernandez E. Vitamin D receptor polymorphisms and diseases. Clin Chim Acta. 2006;371(1-2):1-12

Submit your next manuscript to BioMed Central and we will help you at every step:

- We accept pre-submission inquiries

- Our selector tool helps you to find the most relevant journal

- We provide round the clock customer support

- Convenient online submission

- Thorough peer review

- Inclusion in PubMed and all major indexing services

- Maximum visibility for your research

Submit your manuscript at www.biomedcentral.com/submit 